\title{
Analgesic Effects of Leptadenia hastata Leaf Extract and Neem Seed Oil
}

\author{
Yahaya M Katagum ${ }^{1 *}$, Suleiman Yunusa ${ }^{2}$, Aminu U Kura ${ }^{2}$ and Sani Kawure ${ }^{1}$ \\ ${ }^{1}$ Department of Public Health Technology, Faculty of Basic Medical Sciences, Bauchi State University Gadau (BASUG), Bauchi, Nigeria \\ ${ }^{2}$ Department of Pharmacology, Faculty of Basic Medical Sciences, Bauchi State University Gadau (BASUG), Bauchi, Nigeria \\ *Corresponding Author: Yahaya M Katagum, Department of Public Health Technology, Faculty of Basic Medical Sciences, Bauchi State \\ University Gadau (BASUG), Bauchi, Nigeria.
}

Received: July 15, 2019; Published: July 26, 2019

DOI: $10.31080 /$ ASPS.2019.03.0357

\begin{abstract}
The objective of the present study was to evaluate the phytochemical constituents and to screen for the analgesic activity of methanol leaf extract of Leptadenia hastata and Neem Seed Oil in mice. In this study, analgesic effects of methanol leaf extract of Leptadenia hastata and neem seed sil was evaluated using acetic acid induced pain model. Leptadenia hastata and neem seed oil have been used in traditional folk medicines especially in Africa to treat pain and inflammation. The extract at the dose of $600 \mathrm{mg} /$ $\mathrm{kg}$ significantly reduced the mean number of abdominal writhing as compared to normal saline treated group, inhibiting the pain induced by acetic acid to about fifty (50) percent. Neem seed oi at the doses of 0.8 and $0.25 \mathrm{ml} / \mathrm{kg}$ also significantly and dose dependently reduced the mean number of abdominal writhing induced by acetic acid as compared to control.

In this study, both the extract and neem seed oil produced peripheral analgesia justifying the use of the duo in our localities for treating pain.
\end{abstract}

Keywords: Analgesic; Leptadenia hastata; Neem Seed Oil; Acetic Acid

\section{Introduction}

Pain is an important defensive mechanisms in our body that provides alarming signals to the pathological situations [1]. Pain is defined by the International Association for the Study of Pain as an unpleasant sensory and emotional experience that is linked to actual or potential tissue damage which may be described in terms of such damage [2]. Medicinal plants such as Papaver somniferum have been used for decades to manage pain [3] owing to their availability, cost effectiveness and fewer side effects [4]. Leptadenia hastata is a perennial linna of the family of Ascelepediaceae which pushes in the cattle breeding area of burkinafaso in West Africa [5] and it's widely cultivated in Nigeria for its medicinal as well as nutritional values. Breeders commonly used the leaf stems for placenta retention treatment when animals give birth [5]. Leptadenia hastata has used in traditional medicines especially in Africa to treat pain and inflammation [6]. Leptadenia hastate in Nigeria is commonly known as "Yadiya" (Hausa), "Sobotoroojii" (Fulani), "Iranaji" (Yoruba) and "Isanaje" (Igbo). Has been scientifically evaluated to have numerous pharmacological activities including free radical scavenging activity [7]. Azadirachta indica (meliaceae) is a very useful traditional medicinal plant in the African sub-continent and almost all parts have proven to have substance of pharmacological importance [8]. The plant is also native to Asia and is now commonly cultivated in Nigeria for ornamental and medicinal purposes [8].

\section{Materials and Methods}

Animals

Swiss albino mice weighing 18 to $25 \mathrm{~g}$ irrespective of sex were procured from the animal facility, Department of Pharmacology, Bauchi State University Nigeria. The animals were maintained un- 
der standard laboratory conditions and had free access to food and water in accordance with the principles of laboratory animal care [9].

Drugs, solvents and equipment

Piroxicam (Hovid Pharma., Malaysia), Batch No: BJ10552, NAFDAC No:04-0710. Normal saline, Acetic Acid (Sigma chemical co. St Louis, USA) and distilled water.

\section{Collection of plant material and extract preparation}

The fresh leaves of Leptadenia hastata were collected in the early month of December 2018 at Misau local government Bauchi State Nigeria. The sample was identified and authenticated by Mal. Zainab Zigau of the department of Botany, herbarium section Bauchi State University Gadau Nigeria. The collected plant material was then washed and air-dried. crushed into fine powder using pestle and motor until a significant quantity was obtained. $200 \mathrm{~g}$ of the fine powder was cold macerated with 2 litres of $70 \% \mathrm{v} / \mathrm{v}$ methanol for $72 \mathrm{hrs}$. the resultant mixture was filtered using whattman filter paper number one and then concentrated to dryness using evaporating dish over a water bath at the temperature of $400 \mathrm{C} \pm$ 50C from which percentage yield was calculated and the extract was stored in an air tight container until use. Neem seed oil was procured from Islamic Medicine store located in Katagum Local government Bauchi State Nigeria.

\section{Analgesic screening}

Acetic acid induced pain model

Method followed was similar to that of koster., et al. [10] with minor modifications. 30 mice were randomly divided into five (5) groups $(\mathrm{n}=6)$. group 1 received normal saline $(10 \mathrm{ml} / \mathrm{kg})$, groups ii, iii and iv were pre-treated with the methanol leaf extract of Leptadania hastate (MELH) at the doses of 150, 300 and $600 \mathrm{mg} / \mathrm{kg}$ body weight respectively while group V received piroxicam $10 \mathrm{mg} /$ $\mathrm{kg}$. All treatments were administered orally. One hour post-treatment, each mouse was then injected intraperitoneally (i.p) with $10 \mathrm{ml} / \mathrm{kg}$ of aqueous solution of acetic acid $(0.06 \%)$ and placed in a transparent cage. After five minutes lag period, the number of abdominal constriction accompanied by backward stretching of hind limbs, were counted for each mouse, using tally counters for a period of 10 mins. The same procedure was repeated with the Neem seed oil (NSO) at the doses of $0.3,0.25$ and $0.18 \mathrm{ml} / \mathrm{kg}$ body weight.

\section{Statistical analysis}

Results were expressed as Mean \pm Standard Error of the Mean (SEM). Statistical analysis for difference between means were carried out using one way analysis of variance (ANOVA) followed by Dunnett's post hoc test, $\mathrm{p}<0.05$ were considered statistically significant.

\section{Results}

\begin{tabular}{|l|c|c|}
\hline Treatment (mg/kg) & Mean no. of writhes & \% inhibition \\
\hline N/S $(10 \mathrm{ml} / \mathrm{kg})$ & $22.0 \pm 0.6$ & 0.00 \\
\hline MELH 150 & $17.7 \pm 1.44$ & 19.54 \\
\hline MELH 300 & $13.7 \pm 4.5$ & 37.72 \\
\hline MELH 600 & $10.7 \pm 3.6^{*}$ & 51.27 \\
\hline Pirox. 10 & $8.3 \pm 2.0^{*}$ & 65.27 \\
\hline
\end{tabular}

Table 1: Effect of methanol extract of Leptadenia hastata on acetic acid-induced writhing in mice

Values represents mean \pm SEM. $(\mathrm{p}<0.05)$ using ANOVA; $\mathrm{n}=6, \mathrm{~N} /$ $\mathrm{S}=$ Normal saline, MELH= Methanol extract of Leptodania hastate, Pirox=Piroxicam. ${ }^{*}=$ Statistically significant when compared to normal saline treated group.

\begin{tabular}{|l|c|c|}
\hline Treatment (mg/kg) & Mean no. of writhes & \% inhibition \\
\hline N/S 10 & $21.3 \pm 0.67$ & 0.00 \\
\hline NSO 0.18 & $13.67 \pm 1.86$ & 35.82 \\
\hline NSO 0.25 & $10.67 \pm 3.1^{*}$ & 50.23 \\
\hline NSO 0.3 & $10.0 \pm 2.87^{*}$ & 53.05 \\
\hline Pirox. $(10 \mathrm{mg} / \mathrm{kg})$ & $9.0 \pm 2.61^{*}$ & 57.76 \\
\hline
\end{tabular}

Table 2: Effect of neem seed oil on acetic acid-induced writhing in mice.

Values represents mean \pm SEM. $(\mathrm{p}<0.05)$ using ANOVA; $\mathrm{n}=6, \mathrm{~N} / \mathrm{S}=$ Normal saline, NSO=Neem seed oil, Pirox=Piroxicam. *= Statistically significant when compared to normal saline treated group.

\section{Discussion}

Acetic acid may cause the release of endogenous substances such as histamine, prostaglandins, bradykinins and substance p, which stimulates nerve endings and causes pain [2]. In this study, the ability of the methanol leaf extract of Leptadania hastate at the dose of $600 \mathrm{mg} / \mathrm{kg}$ to inhibit the abdominal writhing (up to $50 \%$ ) 
induced by acetic acid indicates analgesic activity. The significant decrease in the mean number of abdominal constriction this extract at the same dose $(600 \mathrm{mg} / \mathrm{kg})$ when compared with control also suggest analgesic activity.

Neem seed oil at the doses of 0.3 and $0.25 \mathrm{ml} / \mathrm{kg}$ body weight significantly and dose dependently decreased the mean number of abdominal writhing as compared to control group suggesting analgesic like action. Abdominal writhing was inhibited to more fifty percent by both doses signifying marked analgesic activity.

\section{Conclusion}

Methanol leaf extract of Leptadania hastata and neem seed oil possess peripheral analgesic activity justifying the traditional use of both in our localities for treatment of pain.

\section{Conflict of Interest}

Authors declare no conflict of interest.

\section{Acknowledgement}

Authors are grateful to the staff of the laboratory unit, Department of Pharmacology, Bauchi State University Gadau for their technical assistance during the conduct of this research work.

\section{Bibliography}

1. Pushpendra Kumar Patel., et al. "A Detailed Review on Nociceptive Models for the Screening of Analgesic Activity in Experimental Animals". International Journal of Neurologic Physical Therapy 2(2016): 44-50.

2. Harshal N., et al. "Evaluation of analgesic and antipyretic activity of Nigella sativa: an experimental study". National Journal of Physiology, Pharmacy and Pharmacology 6 (2016): 291295.

3. Ahmadiani A., et al. "Antinoceptive and anti-inflammatory effects of Sambucus ebulus rhizome extract in rats". Journal of Enthnopharmacology 61 (1998): 229-235.

4. Bertram GK. "Basic and Clinical Pharmacology" 8ed. McGrawHill Companies. New York. (2001): 596-597.

5. Kerarho J and Adam JG. "The traditional Senegalese pharmacopoeia: Medicinal and poisonous plants". Vigot brother's edition, Paris, London (1974).
6. Dambatta SH and Aliyu BS. "A survey of major ethno medicinal plants of Kano North Nigeria, their knowledge and uses by traditional healers". Bayero Journal of Pure and Applied Sciences 4 (2011): 28-34.

7. Abubakar MS., et al. "In vitro Snake detoxifying action of the leaf extract of Guiera Senegalensis". Journal of Enthnopharmacology 69 (2000): 252-257.

8. $\quad$ Timothy SY., et al. "Antibacterial and Phytochemical Screening of The Ethanolic Leaf Extract of Azadirachta Indica (Neem) (Meliaceae)". International journal of Applied biology and Pharmaceutical Technology (IJABPT) 2 (2011): 194-199.

9. National Institute of Health (NIH). Guide for the care and use of laboratory animals: DHEW Publication, revised, Office of Science and Health Reports, DRR / NIH, Bethesda, USA (1985).

10. Koster R., et al. "Acetic acid for analgesic screening". Federation Proceeding 18 (1959): 412-417.

\section{Volume 3 Issue 8 August 2019}

\section{(C) All rights are reserved by Yahaya M Katagum., et al.}

